\title{
Planned Start Date
}

National Cancer Institute

\section{Source}

National Cancer Institute. Planned Start Date. NCI Thesaurus. Code C133396.

The calendar date that an event or activity is intended to begin. 